\title{
The Impact of a Three-Step Interview on Students' Speaking Ability
}

\author{
Rifda Arafah
}

UIN Fatmawati Soekarno

rifdaarief.edu@gmail.com

\author{
Sudarwan \\ Universitas Bengkulu \\ sudarwan@unib.ac.id \\ Wayan Dharmayana \\ Universitas Bengkulu \\ dharmayana@unib.ac.id
}

\author{
Sakut Anshori \\ Institut Agama Islam Negeri (IAIN) Curup \\ sakutanshori@yahoo.com \\ Prihantoro \\ Institut Agama Islam Negeri (IAIN) Curup \\ prihantoro@iaincurup.ac.id
}

\begin{abstract}
The goal of this study was to determine the impact of employing a ThreeStep Interview on students' speaking abilities. This study's population consisted of all 80 students in their first year at MAN Talang Leak Kabupaten Lebong. The sample consisted of 56 individuals drawn from two courses. The students were separated into two groups: the experimental group got therapy utilizing the Three-Step-Interview method, while the control group was taught using traditional methods. The data will be collected using several methods in the exam. The pre-test will be given once before the therapy begins, and the post-test will be given once the study is completed. This research includes seven treatment meetings. It is based on MAN Talang Leak's academic timetable
\end{abstract}


and semester program. The post-test would be given to the students after they had received seven treatments for each topic. The results from this study will be statistically analyzed using the t-test for the pre-and posttests. The post-test will be used to collect data on the influence of using the Three-Step-Interview method on students' speaking performance. The disparity between the two classes was substantial. According to the data analysis, the outcome demonstrates that the Three-Step-Interview approach may increase students' speaking abilities. It is possible to conclude that the usage of the Three-Step-Interview had a beneficial influence on students' speaking skills. Based on the findings, teachers are advised to utilize the Three-Step-Interview approach when training senior high school pupils to talk.

Keywords: three-step-interview, speaking ability, senior high school students

\section{INTRODUCTION}

One of the linguistic abilities is speaking. When it comes to teaching English as a foreign language, speaking is an important parameter in the textbooks or curriculum development. The speaking teaching technique described above is utilized in the construction of the English language curriculum from elementary through high school. Speaking is one of the basic skills that need communicative competence, pronunciation, grammar, vocabulary, fluency, accuracy, understanding, and gesture improvement, according to (Brown, 2000). These aspects are required to assess pupils' ability to talk using proper techniques. According to (Kartimi, 1985), speaking ability to communicate ideas, intentions, emotions, and feelings to another person using spoken language in such a way that the listener understands what the speaker says. If someone wants to communicate effectively in English, he or she must first acquire proficiency in the language. There are a few things to consider if you want to improve your English language skills. This is based on the fact that language has long been used as a social tool (sociolinguistics), as a personal criterion (behaviorist), and as a mental and symbolic system (psycholinguistic) (Apriani, et. Al, 2019). Furthermore, Budiman (2018) confirmed that the effectiveness of speaking skills is completely dependent on the use, not the usage.

But In reality, when asked to articulate something in English, many senior high school pupils still struggle. As a result, the teacher must be astute in selecting a teaching strategy or technique that is appropriate for 
the student's circumstances and requirements. As a consequence, the aim of teaching and learning is achievable.

During the interview with MAN Talang Leak English teacher, the same condition occurs when the researcher identified that most students in the first year in MAN Talang Leak faced problems in speaking. The interview results revealed a lack of pupils' capacity to talk. First, most students indicated that they could not always begin to talk since it was difficult for them to explain their views. Second, there were issues with grammar and vocabulary, making it difficult for individuals to express themselves verbally. The information above indicates that a particular treatment is needed to improve the students' ability in speaking.

Another problem is the technique that used by teachers is no variation. Students became uninterested in the learning process. Teachers do not use the appropriate technique in teaching speaking that leads students to tend to feel bored. The researcher concluded that there must be a solution or solving problems by applying the technique that can improve students' speaking ability. Cooperative learning is one of the strategies that is thought to be helpful for pupils. The Three-Step Interview Method.

Cooperative learning is a teaching approach in which small groups of students of various levels engage in a variety of learning activities to improve their understanding of a subject. Each team member is responsible not just for learning what is taught, but also for supporting colleagues in learning, fostering an environment of achievement. Students go through the task until all group members understand and successfully finish it. According to (Kagan, 1994), the Three-StepInterview is a cooperative learning technique that allows and encourages group members to participate in absorbing specific concepts profoundly through the role of pupils. In the classroom, it is a malleable process. The goal of this method is to engage pupils in a discussion for analysis and new knowledge synthesis.

In light of the above argument, there should be a strategy that is successful in improving students' knowledge of the English language, particularly their speaking skills. Because most senior high school English teachers offer materials that are dominated by grammar focus, pupils are unable to talk effectively due to a lack of practice and usage of spoken English self.

As a result, in this study, researchers will test the Three-StepInterview approach to improve students' English speaking skills. As a result, in this study, the researcher will employ the Three-Step-Interview approach to help students enhance their English speaking abilities. It is 
believed that by using this approach, pupils' speaking abilities would improve.

\section{THEORETICAL FRAMEWORK}

Speaking is an interchange of thoughts, feelings, emotional expressions, speech, or written form of language, although it is the most often and successfully done through speaking (Utama, 2018). Speaking is important to human communication, which is one of the reasons why it should be taught in language education. When contemplating the function of the human as a social creature that relies on speaking rather than writing when engaging with others, the relevance of speaking ability becomes clear (Nunan, 1993). Speaking, being the initial expression of language has been positioned as a critically essential skill that should be taught with a suitable method (Gusmuliana, et. al, 2020). Speaking is a tool for sending a message to the listener nearly immediately, whether the listener understands or not, and whether the speaker or listener is in control and able to alter the circumstances when sharing his/her idea, or whether he/she is conscious and excited or not (Tarigan, 1996).

According to (Chaney, 1998) Speaking is the process of generating and transmitting meaning in a variety of contexts via the use of verbal and nonverbal cues. Skill is defined as the capacity to perform something well or a certain ability or type of ability. In a nutshell, speaking ability is the capacity to use linguistic knowledge in practical conversation. The ability is used to verbally convey our ideas, feelings, emotions, and needs.

In this study, speaking ability refers to the pupils' capacity to respond after they have spoken test orally in a speaking test that the researcher took from a book that the students used and it has designed based on the material in the syllabus. The result of the test can be shown through the random in little row paper and can be seen after they have been given post-test by the researcher. After that, the score will be gotten between the pretest and posttest that have been done. Whether it will experience increasing students' ability in speaking or not. In the examination of the speech process, four key components are widely recognized: fluency and accuracy of pronunciation, vocabulary, and grammar. As a result, in addition to understanding who, when, and how to practice speaking, the speaker should be well-versed in the key components of speaking.

(Brown, 2000) state there are seven principles in designing teaching speaking techniques: (1) utilize approaches that address the whole range of various learner expectations, ranging from language- 
based accuracy to message-based engagement, meaning, and fluency; and (2) provide naturally stimulating ways. It is necessary to persuade students that the activity will help them learn the target language. (3) promote the use of real language in appropriate circumstances; (4) the authentic language learning environment should be meaningful to the students; (5) offer appropriate feedback and correction, the instructor appreciates students' effort and makes suitable corrections or feedbacks; (6) take advantage of the inherent connection between speaking and listening; the teacher accommodates students not only in the speaking aspect but also in the listening aspect; and (7) provide students with opportunities to initiate oral communication; students are facilitated more frequently in materials related to oral communication so that they are brave to speak.

\section{RESEARCH METHODOLOGY}

Kind of this research is experimental research. Experimental research is research that uses treatment to know the result and to test the hypothesis whether how the relationship between those variables. This study adopted a quasi-experimental method. The term "quasiexperimental" refers to realistic compromises between actual experiments and the nature of human language activity, which we hope to investigate. Such designs are subject to a variety of internal and external validity concerns. Two courses are utilized as inquiry classes in this study. The experiment class receives the Three-Step-Interview method like therapy, whereas the control class receives no treatment. The control group will keep the teaching-learning process going with their teacher. In other words, this class employs the traditional approach of instruction. The data will be evaluated once the pre-test, treatment, and post-test have been completed.

The study's research design may be illustrated below based on the quasi-experimental design:

Table 1: Design of The Research

\begin{tabular}{|c|c|c|c|}
\hline Sample & Pre-test & $\begin{array}{c}\text { Treatm } \\
\text { ent }\end{array}$ & Post-test \\
\hline Experimental & X1e & $\sqrt{ }$ & X2e \\
Class & X1c & $\times$ & X2c \\
Control Class & & & \\
\hline
\end{tabular}


Notes:

X1e: Pre-test student speaking abilities of experimental class

X1c: Pre-test speaking ability of control class students

X2e: Post-test speaking ability of experimental class students

$\mathrm{X} 2 \mathrm{c}$ : Control class student speaking ability in post-test

The population is the entire object or individual that will be investigated in connection with the necessary data. The target population of this study is all of the first-year students of MAN Talang Leak in the academic year 2012-2013.

Table 2. Total The First Year Students at MAN Talang Leak

\begin{tabular}{|r|r|r|r|r|}
\hline \multirow{2}{*}{ Class } & \multicolumn{2}{|c|}{ Sex } & \multirow{2}{*}{ Total } & \multirow{2}{*}{ Population } \\
\cline { 2 - 3 } & \multicolumn{1}{|c|}{ Male } & \multicolumn{1}{|c|}{ Female } & & \\
\hline X.1 & 11 & 17 & 28 & \\
\hline X.2 & 11 & 17 & 28 & 80 \\
\hline X.3 & 11 & 13 & 24 & \\
\hline
\end{tabular}

Source: Documentation of MAN Talang Leak

To select an equal class of sample the researcher uses homogeneity test as follows.

Table 3: Homogeneity Test

\begin{tabular}{|r|r|r|r|}
\hline No & Class & Total Score & Mean Score \\
\hline 1. & X.1 & 1919 & 68,53 \\
\hline 2. & X.2 & 1928 & 68,86 \\
\hline 3. & X.3 & 1503 & 62,63 \\
\hline
\end{tabular}

In selecting the sample, one class is randomly assigned as the experiment class and one as the control class.

Table 4. The Number of Samples

\begin{tabular}{|c|c|c|r|r|}
\hline Class & \multicolumn{1}{|l|}{ Class } & Male & Female & Total \\
\hline Control & X.1 & 11 & 17 & 28 \\
\hline Experimental & X.2 & 11 & 17 & 28 \\
\hline \multicolumn{5}{|c|}{ Total } \\
\hline
\end{tabular}

In this research, techniques of collecting data will be used test to get the data. The pre-test will be administered once before the therapy begins, and the post-test will be administered after the conclusion of the 
study. This research consists of seven meetings of treatment. It is constructed based on the academic calendar and semester program of MAN Talang Leak. After giving seven treatments for each material to the students the post-test would be administrated.

The data of this research will be analyzed by using a t-test for the pre-test and post-test were then calculated statistically. The post-test will be administered to determine the impact of the Three-Step-Interview approach on students' speaking abilities.

The procedures of the experimental class that uses the Three-StepInterview technique include the following: (1) the teacher forms groups of four students signed A, B, C, and D; (2) the teacher introduces the material of the lesson in the class based on the theme on lesson planning; and (3) the teacher conducts the lesson, (3) Each person chooses a partner from among the other members. (4) Individuals interview their partners by asking clarifying questions during the first stage. (5) In the second stage, partners switch roles; (6) In the last phase, members take over the responsibilities of their spouse.

\section{RESULTSS AND DISCUSSION}

\section{Results}

To facilitate understanding the condition of students' speaking ability after the conventional technique is implemented, it is measured based on the result of the post-test given to 28 students in the control class or (X.1). According to pre and post-test, the result of both tests given to 28 students in the control class or (X.1) is to get the highest score, the lowest score, and the mean score. The result of scores calculation by 28 students in the control class presents calculation in the following table :

\section{Table 5. Result of Control Class}

\begin{tabular}{|c|r|r|c|c|l|}
\hline \multicolumn{1}{|c|}{ Test } & $\begin{array}{c}\text { Highest } \\
\text { Score }\end{array}$ & $\begin{array}{c}\text { Lowest } \\
\text { Score }\end{array}$ & $\begin{array}{c}\text { Total } \\
\text { Score }\end{array}$ & $\begin{array}{c}\text { Mean } \\
\text { Score }\end{array}$ & $\begin{array}{l}\text { Standard } \\
\text { Deviation }\end{array}$ \\
\hline Pre & $\mathbf{6 7}$ & $\mathbf{3 1}$ & $\mathbf{1 3 0 6}$ & $\mathbf{4 6 , 6}$ & $\mathbf{7 , 3}$ \\
\hline Post & $\mathbf{6 8}$ & $\mathbf{3 4}$ & $\mathbf{1 3 4 2}$ & $\mathbf{4 7 , 9}$ & $\mathbf{7 , 0 8}$ \\
\hline
\end{tabular}

From the table above, it showed that in the control class the outcome of calculating the scores of 28 students in the control class in the pre-test demonstrates that they have a mean score of 46,6 and a standard deviation of 7,3. And the outcome of calculating the scores of 28 students in the control class in the post-test demonstrates that they have a mean score of 47,9 and a standard deviation of 7,08. 
Based on the finding, the data referring to students' highest score achieved $>60$ acquired by 1 student. Whereas, the students' are lowest score reached 31 by one student. This condition indicated that 26 of the students' gained the pre-test result $>31$ till $<60$. Next, the total score of students in the pretest was 1306. Based on the total score, the researcher could take the mean score by dividing the amount of total score by students' amount in which the calculation achieved the result in the amount of 28. The standard score on speaking is 60 . That's means 27 students who reached the standard score. Then, as the last process in this context, the researcher calculated the standard deviation.

From pre-test and post-test data, the comparative result of scores calculation presents the calculation in the following chart:

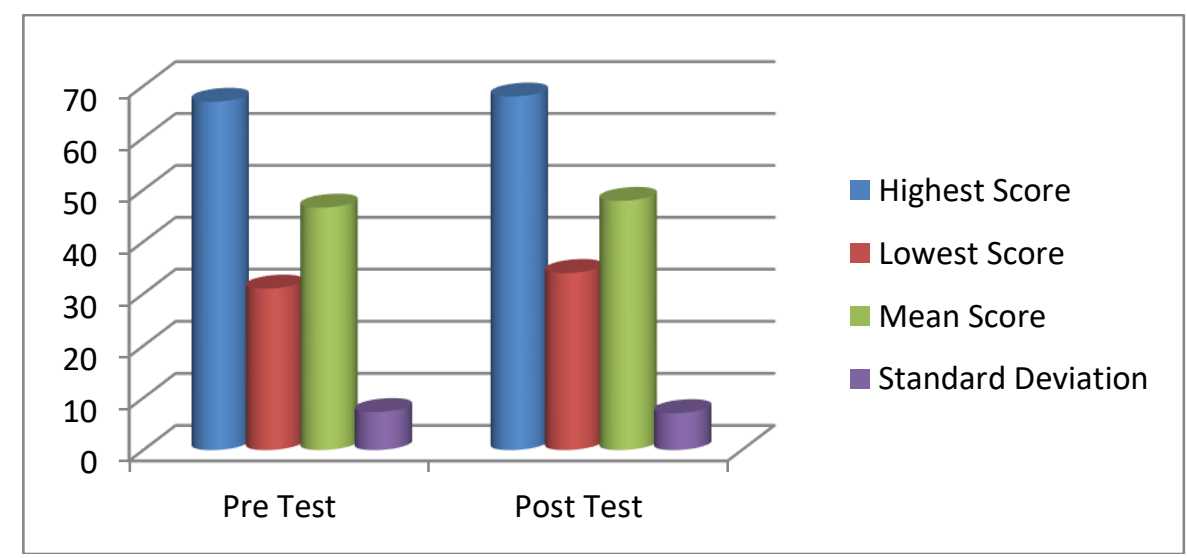

\section{Chart 1. The Comparative Result between Pre and Post Test of Control Class}

Based on the results of pre and post-tests administered to 28 students in the experimental class, the condition of students' speaking ability before and after the implementation of the Three-Step-Interview can be shown (X.2). According to the before and post-test results, the greatest, lowest, and mean scores were obtained by the 28 students in the experiment class or (X.2). The following table shows the results of the scores calculated by 28 students in the experiment class:

Table 6. Result of Experiment Class

\begin{tabular}{|c|r|r|c|c|l|}
\hline \multicolumn{1}{|c|}{ Test } & $\begin{array}{c}\text { Highest } \\
\text { Score }\end{array}$ & $\begin{array}{c}\text { Lowest } \\
\text { Score }\end{array}$ & $\begin{array}{c}\text { Total } \\
\text { Score }\end{array}$ & $\begin{array}{c}\text { Mean } \\
\text { Score }\end{array}$ & $\begin{array}{l}\text { Standard } \\
\text { Deviation }\end{array}$ \\
\hline Pre & $\mathbf{5 9}$ & $\mathbf{2 5}$ & $\mathbf{1 2 8 7}$ & $\mathbf{4 6 . 0}$ & $\mathbf{8 . 3 7}$ \\
\hline
\end{tabular}




\begin{tabular}{|l|l|l|l|l|l|}
\hline Post & 76 & 38 & 1615 & 57.7 & 7.15 \\
\hline
\end{tabular}

After the researcher did the pretest, the researcher did treatment. To know the result of treatment and answer the question of student speaking ability under the teaching by using the Three-Step-Interview technique, so the researcher did the posttest. The data analysis of posttest results in finding, the researcher could give the conclusion that the students' scores were good than pretest result. It can be seen from the highest score, the lowest score, total score, mean score, and standard deviation.

From pre-test and post-test data, the comparative result of scores calculation presents the calculation in the following chart:

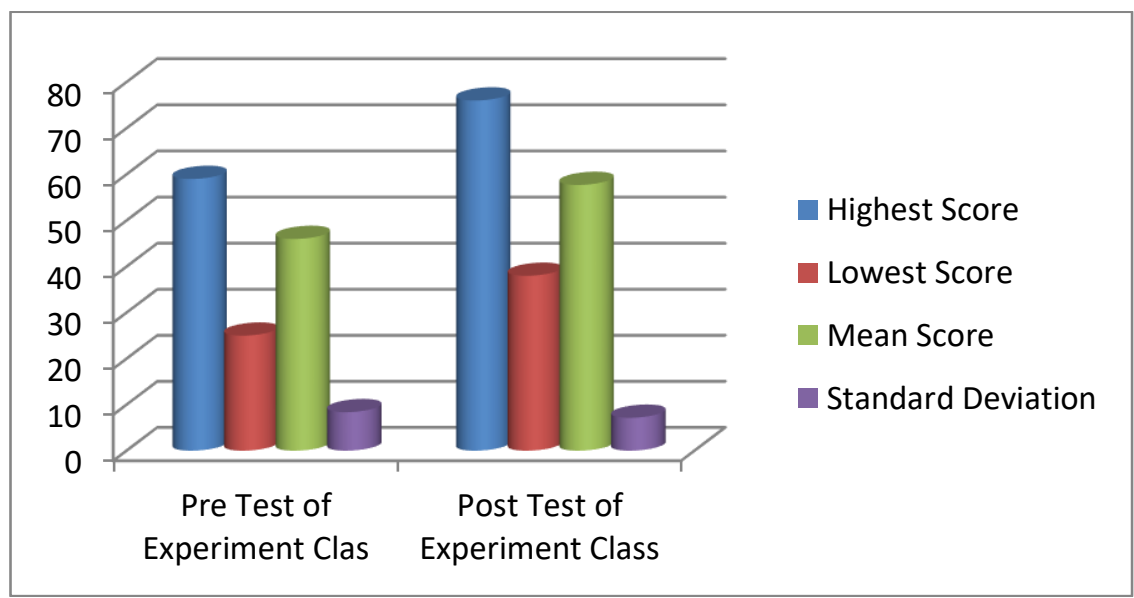

\section{Chart 2. The Comparative Result between Pre and Post Test of Experiment Class}

The effect of the Three-Step-Interview in improving speaking ability can be looked at based on data analysis of comparison the data got by both classes. The researcher gives three criteria to know how effective the Three-Step-Interview used in speaking ability those are the mean score, standard deviation, and student score. The following table and chart may help the clarification and contain comparative results from the experimental and control classes below:

Table 7. The Comparative Result between Control and Experimental Class

\begin{tabular}{|l|l|l|l|l|} 
Class & Mean score & $\begin{array}{l}\text { Standard } \\
\text { deviation }\end{array}$ & $\begin{array}{l}\text { Students } \\
\text { who get a a } \\
\text { score }>60\end{array}$ & $\begin{array}{l}\text { Students } \\
\text { who get a } \\
\text { score }<60\end{array}$ \\
\hline
\end{tabular}




\begin{tabular}{|l|c|c|c|c|c|c|c|c|}
\hline & $\begin{array}{c}\text { re } \\
\text { Test }\end{array}$ & $\begin{array}{c}\text { ost } \\
\text { Test }\end{array}$ & $\begin{array}{c}\text { re } \\
\text { Test }\end{array}$ & $\begin{array}{c}\text { ost } \\
\text { Test }\end{array}$ & $\begin{array}{c}\text { re } \\
\text { Test }\end{array}$ & $\begin{array}{c}\text { ost } \\
\text { Test }\end{array}$ & $\begin{array}{c}\text { re } \\
\text { Test }\end{array}$ & $\begin{array}{c}\text { ost } \\
\text { Test }\end{array}$ \\
\hline Control & 6.6 & 7.9 & .3 & .08 & & & 7 & 6 \\
\hline Experimental & 6.00 & 7.7 & .37 & .15 & & 0 & 8 & 8 \\
\hline
\end{tabular}

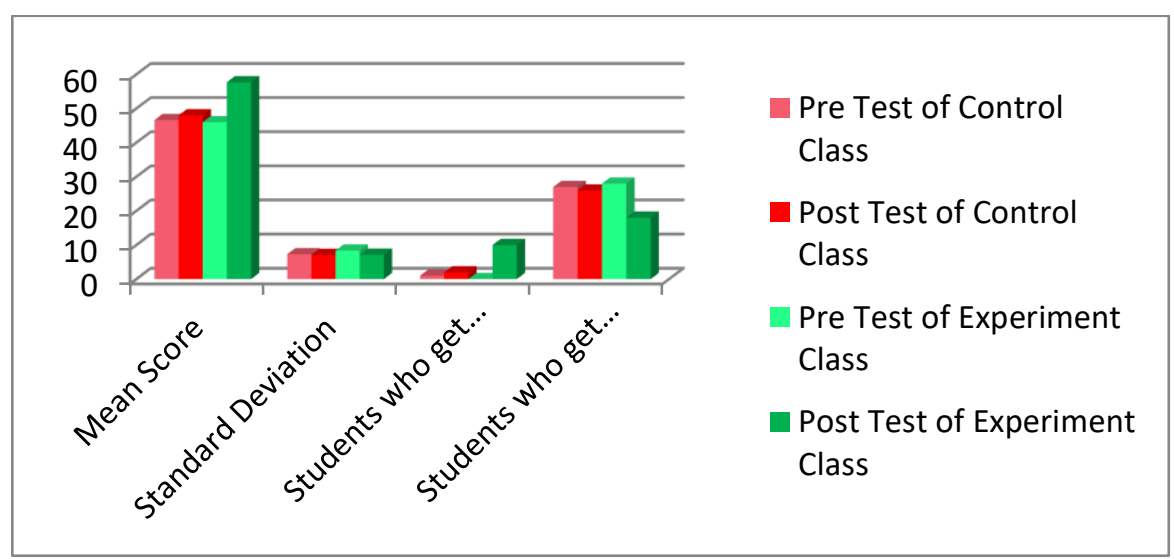

\section{Chart 3. The Comparative Result between Control Class and Experimental Class}

According to the data presented in the table above, the control class's mean pre-test score is 46,6 and its mean post-test score is 47,9 . One student earned a score of more than 60 on the pre-test, while 27 students received a score less than 60 on the post-test. Meanwhile, the experimental class's pre-test mean score is 46,00 , and its post-test mean score is 57.7. Furthermore, in the pre-test, no student had a score greater than 60 , and all received a score of 60 , but in the post-test, 10 students received a score greater than 60, and 18 students received a score of 60 .

According to the statistics shown above, the rise in the score of the control class is not larger than the increase in the score of the experimental class. The control group's mean pre-test score is 46.6, whereas the mean post-test score is 47.9. It only earns 1.34 points. Meanwhile, the experimental class had a mean pre-test score of 46.0 and a mean post-test score of 57.7. It raises by 11.7 points. Following therapy, both groups were subjected to a post-test utilizing the same oral test. The therapy was successful since the experimental class's post-test score was greater than the control classes, which was 11.7 points. As a consequence, it is possible to conclude that the therapy has a substantial influence on 
the experimental class, as evidenced by the range of post-test results for both classes.

The researcher utilized this to determine the hypothesis of this study. The formula for the t-test determines if the " $t$ " obtained indicates a significant difference between the mean scores of the control and experimental classes. Based on the researcher's examination of the data from both courses, the researcher must conclude that the Three-StepInterview helped enhance students' speaking skills. Even though the computation is still required since it determines whether the alternative hypothesis is accepted or not. The t-formula was used to compute data from both classes, which can be seen in the presentation below:

Standard deviation in experimental class is $\mathbf{7 . 1 5}$ and standard deviation in control class $\mathbf{7 . 0 8}$, so the t-test is $\mathbf{5 . 1 0}$

The $t$ table

$$
\begin{array}{ll}
\mathrm{df} & =\mathrm{tN} 1+\mathrm{N} 2-2=\mathrm{t} 28+28-2=\mathrm{t} 54 \\
\mathrm{df} & =2.004
\end{array}
$$

The t-table is $\mathbf{2 . 0 0 4}$

t-test $>\mathrm{t}$-table $\quad=\quad \mathrm{H} 1$ is accepted

$\mathrm{t}$-test $<\mathrm{t}$-table $=\mathrm{H} 0$ is rejected

In this research got $5.10>2.004=\mathrm{H} 1$ is accepted $\& \mathrm{H} 0$ is rejected

The t-test value was 5.10, according to the findings of the matched t-test computation. And, at the 95 percent significant level, the $t$-table value was 2.004 with a degree of freedom (df) of 54, suggesting that $\mathrm{H} 0$ is rejected and $\mathrm{H} 1$ is accepted. In other words, during the academic year $2012 / 2013$, teaching speaking utilizing the Three-Step-Interview technique was effective in developing speaking skills in the First Year of MAN Talang Leak.

\section{Discussion}

The student speaking ability under the teaching using the conventional technique was not good yet. Most of the students obtained low scores than the score of standard competence. According to Ur (1996, p. 121), several factors influence students'" ESL speaking-learning. The familiar factors are inhibition, today, low or uneven participation, and preferring to use their L1, mother tongue. Thus, these factors take into account some of the students" problems in mastering speaking skills. This fact was described based on the outcome of the pretest It was demonstrated by the data obtained as a consequence of administering a pre-test to pupils in the control class. The pretest was administered to all 
students in the control class. There are 28 pupils in total. The researcher obtained the highest, lowest, total, mean, and standard deviation scores from the pretest.

Based on the finding, the data referring to students' highest score achieved $>60$ acquired by 1 student. Whereas, the students' are lowest score reached 31 by one student. This condition indicated that 26 of the students' gained the pre-test result $>31$ till $<60$. Next, the total score of students in the pretest was 1306. Based on the total score, the researcher could take the mean score by dividing the amount of total score by students' amount in which the calculation achieved the result in the amount of 28. The standard score on speaking is 60. That's means 27 students who reached the standard score. Then, as the last process in this context, the researcher calculated the standard deviation. From students' scores, the standard deviation was used to analyze how high the value of a variable shifted from the mean score. The result of the calculation for standard deviation reached the amount of 7.3.

To answer the question of how is the student's speaking ability under the teaching using a conventional technique, the researcher got the answer from the result of the post-test. The researcher found that there was a significant improvement in students' scores in the control class based on data analysis of post-test results in finding. It is evident from the mean score, greatest score, lowest score, total score, and standard deviation. To begin, the average score was 47.9. The mean score improved from the pretest mean score of 46.6. It was around 1.34 points. Second, one student had the highest posttest score of 68 , while another received the lowest score of 34 . In the pretest, one student had a score of 67 , while another received a score of 31 . It implies that there was an improvement in the students' performance and scores from pretest and posttest. On another side, because the highest score in the posttest result was 68 so there was one student who passed in the post-test. Third, the total score in the posttest was higher than the pretest. The total score was 1342 . Therefore the difference was 36 points. Last, the standard deviation of the posttest score was higher than the pretest. The difference between both of them was 0.22 points. It indicates that students' motivation was increased and they were more active to follow the teacher's instructions. As Kagan (1994) stated that the use of the TSI approach in teaching ESL speaking inspired and energized students to talk more effectively while also instructing them in how to inquire, answer, and exchange information. In conclusion, pupils' speaking abilities improved little while being taught utilizing traditional techniques. 
In the pretest, students' speaking abilities under the teaching of the Three-Step-Interview approach get a comparable score as the control class. Students' speaking abilities were still lacking. The majority of pupils had lower results than the standard competency score. This fact was described based on the result of the pretest. It was proven by the data found out on the result of giving pre-test to students at experiment class. The pretest was given to all of the students in the experiment class. The data of the pretest showed the highest score, lowest score, total score, mean score, and also standard deviation.

Based on the finding, the data referring to students' highest score achieved 59 acquired by one student. Whereas, the students' are lowest score reached 25 by one student. This condition indicated that 26 students gained the pre-test result $>25$ till $<59$. Next, the total score of students in the pretest was 1287. Based on the total score, the researcher could take the mean score by dividing the amount of total score by students' amount in which the calculation achieved the result in the amount of 46.0. The standard score for speaking is 60 . So, were nothing student who reached the standard score. Then, as the last process in this context, the researcher calculated the standard deviation from students' scores. Standard deviation was used to analyze how high the value of a variable shifted from the mean score. The result of the calculation for standard deviation reached the amount of 8.37.

After the researcher did the pretest, the researcher did treatment. To know the result of treatment and answer the question of student speaking ability under the teaching The researcher conducted the posttest utilizing the Three-Step-Interview method. After analyzing the data from the posttest findings, the researcher was able to conclude that the student's scores were higher than the pretest results. The highest score, lowest score, total score, mean score, and standard deviation all show this.

First, the mean score of students in the posttest result was 57.7, with one student receiving the highest score of 76 and one receiving the lowest score of 38. It differs from the outcome of the pretest. In the posttest, 10 students reached the standard score. Whereas in pretest nothing student who reached the standard of the score. Students' scores improved from pretest to posttest results. The increase of mean score was 11.7 points. Second, the total score in the posttest was higher than the pretest score. The increase was 328 points from 1287 to 1615. Last, the standard deviation was lower than the pretest. It was 8.37 to 7.15 . The difference was 1.22 points. It means that students' interval score in the posttest was not far from its mean score. So the score of each student is 
closed to their mean score. According to Kagan (1994) and Thirumalai (2002), the method encourages pupils to communicate effectively. In conclusion, pupils' speaking skills improved after being taught utilizing the Three-Step-Interview approach.

The researcher used the Three-Step-Interview approach to determine the influence of student's speaking abilities. The therapy was implemented throughout the course of seven encounters. After administering the therapy, the researcher administered the posttest to both classes. The posttest results for both courses would be compared. As a consequence of the calculations, the experimental class outperformed the control class. It proved from some aspects that would be compared.

First, the mean posttest score in the control group was 47.9. The mean score in the experiment class was 57.7. Based on this background, it was determined that the experiment class outperformed the control class. The Three-Step-Interview approach, on the other hand, has a greater impact on developing pupils' speaking skills than conventional techniques.

Second, the overall posttest score in the experiment class was 1615. It was higher than in the control group. The overall posttest score in the control group was 1342. The difference in scores was 273. Because of the difference, the control class had a lower score than the experiment class. It may be observed from the maximum score obtained in the experiment, which was 76 , and the lowest score obtained by one student, which was 38. In the control class, the best score was 68 obtained by one student, while the lowest score was 34 obtained by one student.

In addition to the two factors mentioned above, the researcher computes a t-test to ensure that Three-Step-Interview improves students' speaking skills. Before calculating the $t$-test, the researcher must first understand the hypothesis in this study. The first hypothesis is H0, which states that the Three-Step-Interview approach influences pupils' speaking abilities. The next hypothesis is H1, which states that the Three-StepInterview approach does not influence students' speaking abilities. The researcher obtained the value of $t$ using the $t$-test, which is 5.10 . To determine the value of the $t$-table, the researcher must first determine the degree of freedom. Then there's the matter of the degree of freedom, which is 54 . The t-table value is 2,004. This indicates that the t-test is greater than the t-table. As a result, the initial hypothesis, $\mathrm{H} 0$, is rejected, whereas $\mathrm{H} 1$ is accepted. According to Kamaliah et al. (2018), the threestep Interview approach may be regarded as an excellent alternative method for developing students' speaking abilities. Utama (2018) also mentioned that Three-StepInterview is anticipated to be utilized as a 
method for the instructor to teach in speaking since this strategy motivates, enjoys, and requires all students to be more engaged and passionate in the teaching-learning process. It is possible to conclude that the Three-Step-Interview approach improves students' speaking abilities.

\section{CONCLUSION}

Students' speaking skills after using the usual approach in the control class are in poor condition. It can be observed that the score in the control class increased by 1.34 points between the pretest score of 46.6 and the post-test level of 47.9. Pupils' speaking ability after using the Three-Step-Interview approach is good since students in the experimental class have an improving ability. The mean score of the pretest in the experiment class is 46.0 , with a standard deviation of 8.37. According to the post-test results, the mean score of the experiment class is 57.7, with a standard deviation of 7.15. The score in the experiment class has increased by 11.7 points. The Three-Step Interview method is excellent in enhancing students' public speaking skills. The outcome of the " $t$ " computation represents the fact. To test the hypothesis, the researcher does the " $t$ " calculation. According to the computation, the figure of " $t$ " discovered is 5.10, while the value of the " $t$ " table is 2.004 . The researcher then compares the two results. The comparison shows that 5.10 is more than 2.004. According to the data analysis, the outcome demonstrates that the Three-Step-Interview approach may increase students' speaking abilities.

\section{REFERENCES}

Apriani, E., Anshori, S., \& Edy, S. (2019). Eksistensi English Zone Sebagai Media Penerapan Kemampuan Berbahasa Inggris Mahasiswa Program Studi Tadris Bahasa Inggris IAIN CURUP. Cendekia: Jurnal Kependidikan Dan Kemasyarakatan, 17(2), 317-332.

BNSP, 2006. Petunjuk Teknis Pengembangan Silabus dan Contoh/Model Silabus. Jakarta : Departemen Pendidikan Nasional.

Budiman, W. (2019). Students' Perception Of Lecturers' Role In Enhancing Efl learners' Communication Ability (A Study At Eight Semester On Academic Year 2018 In IAIN Curup) (Doctoral dissertation, IAIN Curup).

Chaney, 1998, Teaching Oral Communication in Grades, Boston: Allyn \& Bacon. 
Dimyati \& Mudjiono. 1999. Belajar dan Pembelajaran. Jakarta : PT Rhineka Cipta.

Gusmuliana, Paidi, Eka Apriani, and Syafryadin Syafryadin. "Improving Students Speaking Motivation by Using Role Play Technique at Institute Islamic in Indonesia." (2021): 356-361.

Harta, English Teacher of MAN Talang Leak, Interview. on February 20th, 2013.

Hatch, Evelyn, and Farhady, Hussein. 1982. Research Design and Statistic for Applied Linguistic. Massachusetts: Newburry House Publishing Inc

Hornby, AS. 1995. Oxford Advanced Learner's Dictionary of Current English. England : University Press

Huda, Miftahul. 2012. Cooperative Learning. Metode, Teknik, Struktur, dan Model Penerapan. Yogyakarta : Pustaka Pelajar.

Hughes, Arthur. 1989. Testing for Language Teacher. Cambridge : Cambridge University Press.

$\begin{array}{cccc}\text { Kagan. } & 1994 . & \text { Three-Step } & \text { Interview: } \\ \text { http://www.kaganonline.com/Newsletter/techtip.html } & \end{array}$

Kagan, S \& Kagan, M. 2009. Kagan Cooperative Learning. San Clemente: Kagan Publishing.

Kamaliah, N. (2018). Use of The Three-Step Interview Technique in Teaching ESL Speaking. English Education Journal, 9(1), 82-101.

Nana, Sudjana. 2004. Penelitian dan Penilaian Pendidikan, Bandung : Sinar Baru Algesindo.

Nunan, D. 1993. Research Methods in Language Learning. New York : Cambridge University Press.

$\begin{array}{lllll}\text { Orwig, } & \text { C. J. } & \text { Speaking } & \text { Skill. } & \text { Article. }\end{array}$ http://www.sil.org/lingualinks/language learning/OtherResources/G/SpeakingSkill.html

Oxford Advance Learner's Dictionary. 1995. Oxford : Oxford University Press.

Priyana, Joko. 2006. Interlanguage. English for Senior High School Students Year X. Jakarta : Pusat Perbukuan Departemen Pendidikan Nasional.

Slavin. 1995. Cooperative Learning: Theory, Research, and Practice Second Edition. Massachusetts: Allyn and Bacon Publisher.

Sudarwati, 2007. Look Ahead An English Course for Senior High School Students Year X. Jakarta : PT. Gelora Aksara Pratama.

Sudijono. Anas. 2008. Pengantar Statistik Pendidikan. Jakarta : Raja Grafindo Persada.

Suharsimi, Arikunto. 1993. Prosedur Penelitian. Rineka Cipta: Yogyakarta. 
Tarigan, Henry G. 1996. Berbicara Sebagai Suatu Keterampilan Berbahasa. Bandung : Angkasa.

Thirumalai, M. S. (2002). An introduction to TESOL: Teaching English to Speakers of Other Languages. Language in India, 2(2). Retrieved January 4, 2017 from <http://www.languageinindia.com/april2002/tesolbook.html\#cha pter5>.

Thornbury, S. 2005. How to Teach Speaking. London: Pearson Education Limited

Ur, P. (1996). A course in language teaching: Practice and theory. Cambridge: CUP.

Utama, I. M. P. (2018). The Effects of Three Step Interview Strategy Towards Students' Speaking Ability. Jurnal Paedagogy, 5(2), 104109.

Utami, Rela. 2010. Improving Speaking Skill Using Three-Step-Interview (A Classroom Action Research in the First Grade Students of SMA Negeri 1 Ngawi in the academic year 2009/2010). Thesis. Surakarta : Sebelas Maret University. 
232 | ENGLISH FRANCA, Vol. 5, No. 2, 2021 